\title{
Does Political Connection, Executive Character, and Audit Quality Affect the Tax Avoidance Practice? Evidence in Indonesia
}

\author{
Diah Amalia | Steven Ferdiansyah \\ Department of Managerial Accounting, Politeknik Negeri Batam, Indonesia
}

\begin{abstract}
This study aim to find the empirical evidence of the effect of political connection, executive characters, and audit quality on tax avoidance practice in Indonesia. This research uses annual reports of the manufacturing companies that are listed in Indonesian Stock Exchange (IDX) period 2013 - 2017. Using purposive sampling, this study obtained 51 companies that fulfill the criteria of 165 companies as total population, so the total observation for 5 years is 255 samples. The data was examined using multiple regression analyses with data panel. Tax avoidance practice in this research is proxied by Cash ETR. The results of this study indicate that variable political connection has significant positive effect on tax avoidance, which means that the average company uses its political connections to lower tax payments. Variable executive characters have no significant effect on tax avoidance, which means that the characters of executive not yet able to become a standard for determining tax avoidance practice. Variable audit quality indicated no significant effect on tax avoidance, which means the taxation office (KAP) the big four who has a good quality hasn't been able to conclude the company not doing tax avoidance practice.
\end{abstract}

Keywords: Tax Avoidance Practice, Political Connection, Executive Character, Audit Quality

\section{Introduction}

The percentage of state revenue through taxes in Indonesia is very dominant than other revenue sources. The dominance of sources of state revenues through the tax sector forces the government to roll out various policies to governing taxation in Indonesia. Policies regarding taxation made by the government are used as a benchmark in making tax payments. In fact, even though there are tax laws that regulate, there is a possibility that loopholes in cheating such as the practice of tax avoidance. Of course, this causes the source of state revenue not work as it should.

Based on data from Ministry of Finance of the Republic of Indonesia, Indonesia's tax ratio tends to be lower than neighboring countries in Southeast Asia Region. The low tax ratio can be explained by the buoyancy indicator or comparisons between the growth of tax revenues with the growth of Indonesia's economy which has decreased. Tax revenues in 2018 actually experienced a double digits growth compared to 2017 of 14,33\% year on year (yoy). In terms of tax revenue performance in 2018, it is known that Direktorat Jendral Pajak (DJP) was able to collect 1.315,93 IDR trillion or 92,41\% of the 1.424,00 IDR trillion targeted in APBN 2018 (Kementerian Keuangan, 2019b). This shows that the performance of taxation in Indonesia has not yet reached the target of the determined by APBN or has experienced a shortfall of 108,07 IDR trillion.

The tax revenue realization deficit can be caused as a result of tax avoidance practice. In line with the statement by Astuti \& Aryani (2016) which states the tax revenue that does not reach the target is due to the low compliance of tax deposits, there are still many unrecorded transactions (underground economy), and tendency to doing the tax avoidance practice. Revenue figures that do not meet the target are also supported by the low level of Indonesian taxpayer compliance (www.pajak.go.id). Avoiding tax payments is one form of non-compliance with taxpayers so that the tax revenues are not optimal. 
The complexity of the relevance between the interests of the government and taxpayers has triggered problems in non-compliance with taxation in Indonesia. In line with the statement by Maharani \& Suardana (2014) who also mentioned that the practice of tax avoidance is a complicated issue, this is due to the fact that tax avoidance is an act that is permissible, but on the other hand, the government doesn't want this practice. Butje \& Tjondro (2014) also mentioned that the nature of tax avoidance is legal in the eyes of the law causes the tax authorities can not impose penalties on violators.

Disclosure the involvement of directors and commissioners in politics is not fully regulated in Indonesia laws besides the regulation of Politically Exposed Person (PEP) on financial services. This raises the suspicion that political connection can be a factor in tax avoidance. Research by Ferdiawan \& Firmansyah (2017) proves that there is an influence between political connections to tax avoidance, and the average of the company uses their political connections to reduce tax payment through lobbying activity and looser supervision.

The role of an executive also influences company policies in carrying out tax avoidance. The characters of an executive are divided into a risk-taker and risk-averse (Low, 2009). A risk-taker more takes the risk to do tax avoidance, different from a risk-averse who tends to avoid the risk of tax avoidance. Research by Maharani and Suardana (2014) proves that the more an executive with a risktaker character, causing the greater the tax avoidance practice.

Another factor suspected of having a role in tax avoidance is audit quality. Competent parties such as KAP the big four usually tend to present a better financial report audited results so that the tax avoidance policies are difficult to do. That statement is in line with Eksandy (2017) which states that companies who use KAP the big four in auditing financial statements have a higher level of difficulty in conduction aggressive tax policies.

There are differences in results and assumptions in several studies make researchers want to test further to find out the consistency of the result on the applications of different samples. This study uses the basis of research conducted by (Y and Niandari, 2018) which examines the influence of political connection, company characteristics, and audit quality on tax avoidance as measured by ETR in the banking sector listed on Indonesian Stock Exchange (IDX) period 2014 - 2016 with the number of samples is 39 companies.

This study has several differences from previous studies, including the use of executive character variables that are thought to have a role in tax avoidance practice. Researcher also changed the measuring instrument to Cash Effective Tax Rate (Cash ETR) which represented the tax avoidance practice variable, because according to Dyreng et al. (2008) Cash ETR is not affected by changes in estimates such as valuation allowance or tax cushion, and according to Astuti and Aryani (2016) referring to Hanlon and Heitzman (2010) that Cash ETR is often used as a proxy for tax avoidance and in accordance with tax regulations in Indonesia. This study uses the manufacturing sector listed on the Indonesian Stock Exchange (IDX) as the object of research because that sector is the dominant sector on IDX. The time horizon in this research for 5 years using the latest year is $2013-2017$. The problem that can be formulated in this study is to examine whether there are influences of political connection, executive characters, and audit quality on tax avoidance practice. In line with the formulations of the problem, the purpose of this study aims to know and find empirical evidence about the effect of political connection, executive characters, and audit quality on tax avoidance practice in Indonesia.

\section{Theory review, literature, and hypothesis development Theoretical Review \\ Agency Theory}

The discussion of agency relations has been explained by Jensen and Meckling (1976) which states that a company is formed from a collection of contracts between two interested parties, namely the owners of economic resources as principal and managers of resources as the agent. Ferdiawan and Firmansyah (2017) indicate that the problem regarding agency appears when it's assumed that agents have an attitude that tends to follow their own desires (self-interest).

\section{Stewardship Theory}

According to Donaldson and Davis (1991), this theory has been designed based on psychology and sociology for executives as stewards to be motivated to act in line with the wishes of principals. 
This theory further illustrates how a leader or steward isn't motivated by the goals of individualism. This is confirmed by the statement of Davis et al. (1997) which revealed executives weren't motivated by their personal desires.

\section{Positive Accounting Theory}

The theory developed by Watts and Zimmerman (1990) is a theory that describes how a manager predicts policies to be taken under certain conditions. Positive accounting theory also emphasizes the freedom to choose one alternative from several accounting policies with the aim of maximizing the value of the company. The freedom to choose makes a manager tend to take opportunistic actions. This theory describes 3 types of hypotheses that represent accounting policies, namely the bonus plan, the debt covenant, and political cost.

\section{Stakeholder Theory}

According to Freeman (1984), stakeholders are groups or individuals who can influence each other by achieving certain goals. Stakeholder theory states that a company isn't an entity that only operates on the basis of its own interests but must provide benefits to stakeholders. The company must strive to maintain good relations by meeting the needs and desires of stakeholders, especially for stakeholder who have strong power related to the availability of resources (Ghozali and Chariri, 2007).

\section{Tax Avoidance Practice}

Tax avoidance practice is all forms of activities that have an effect on tax liability, both allowed activities and special activities to reduce the tax expense (Dyreng et al., 2008). The act of avoiding taxes made by the company only intends to take advantage of legal weaknesses, therefore this doesn't violate applicable laws. This statement is in line with Butje and Tjondro (2014) which states that tax avoidance isn't a violation of the law, but is an act of taking profits by understating of tax liability.

\section{Political Connection}

The company that indicated there is a political connection is a company that utilizes a variety of ways, in order to have political or try to get closer to politicians and government (Pranoto and Widagdo, 2016). The existence of political ties can be used to achieve certain goals by providing benefits to both parties (Purwanti and Sugiyarti, 2018). Politically connected companies tend to be brave enough to take action to minimize their tax expenses, considering the low risk of the company to be examined (Kim and Zhang, 2016). The political connection factor increasingly urging company management to find a way to improve its relationship with the leadership of the state or political party (Li et al., 2016).

\section{Executive Character}

When carrying out his duties as the head of the company, Low (2009) mentions an executive has two characters namely risk-taker and risk-averse. The determination of executive character can be seen from corporate risk. When a company shows high risk, the executive who leads the company tends to be characterized by risk-takers. Otherwise, when a company shows low risk, the executives who lead the company tend to be characterized by risk-averse (Kartana and Wulandari, 2018).

\section{Audit Quality}

Audit quality is defined as all possibilities that can occur when the auditor doing audit the client's financial statement and find violations which then report them to the audited financial statements (DeAngelo, 1981). A company will trust the competent auditor in conducting the audit process in its financial statements. Annisa and Kurniasih (2012) explained that based on several references, when a company uses the services of KAP the big four in auditing their financial statements, the result presented a higher level of quality.

\section{Literature Review}

The result of research by Butje and Tjondro (2014) found a positive effect of political connection variables on tax avoidance practice in non-financial companies. The results of the study were proven 
again by Utari and Supadmi (2017) in property and real estate companies and Ferdiawan and Firmansyah (2017) in manufacturing companies who both found political connection had a positive effect on tax avoidance. Different from Tehupuring and Rossa (2016) and Y and Niandari (2018) in the banking sector, the political connection has a negative effect on tax avoidance. Other results that prove the political connection does not affect tax avoidance practice by Lestari and Putri (2017) the object of research in all sectors of the company in Indonesia.

The research about the effect of executive character on tax avoidance has been carried out by Maharani and Suardana (2014) in the manufacturing sector who found a positive influenced. The same results proved by Dewi et al. (2016) in the mining sector that finds executive character has a positive effect on tax avoidance. Different directions are shown in the Carolina et al. (2014), Butje and Tjondro (2014), and Novita (2016) who found negative effects of executive character on tax avoidance. The results that show no influence of executive character on tax avoidance have been proved by Kartana and Wulandari (2018) and Nengsih et al. (2018).

Dewi and Sari (2015) in their research on manufacturing companies proved that audit quality has a positive influence on tax avoidance. These results contradict by Mulyani et al. (2018) who found a negative effect of audit quality on tax avoidance at mining companies. The results that prove audit quality is not influenced by tax avoidance practice were shown in several studies, like Tehupuring and Rossa (2016), Y and Niandari (2018), and Kartana and Wulandari (2018).

\section{Hypothesis Development}

\section{Effect of Political Connection on Tax Avoidance Practice}

Disclosure the involvement of directors and commissioners in politics is not fully regulated in Indonesia laws besides the regulation of Politically Exposed Person (PEP) on financial services. This causes some politically connected companies to indirectly get some special treatment and benefits. In line with the statement of $\mathrm{Y}$ and Niandari (2018) and Butje and Tjondro (2014) which states that companies will get special treatment when having political connections, such as easy to obtain a capital loan and the risk of a low tax audit. These indications cause companies to be more aggressive in implementing tax planning so that financial report transparency decreases.

Politically connected companies will use special relationships with the government to carry out tax avoidance. That allegation was supported by Faccio (2006) who stated that politically connected companies tend to pay lower taxes. The results of research that support the researcher's allegation have been carried out by Butje and Tjondro (2014), Utari and Supadmi (2017), and Ferdiawan and Firmansyah (2017) who found a positive effect on political connection to tax avoidance. Based on the researcher's expectations and the description, the first hypothesis in this study is:

\section{$H_{1}$ : There is a positive effect of political connections on tax avoidance practice.}

\section{Effect of Executive Character on Tax Avoidance Practice}

An executive basically has different characters. The difference from executive character will be reflected in company policymaking, including the tax avoidance practice. According to Low (2009) mentions that executives have two different characters, namely a risk-taker and a risk-averse. The risk-taker will use their courage to take more risks in tax avoidance practice, while risk-averse will avoid taking these risks. The executive character will be seen from the risk of the company.

The executive who dares to take a large risk will be expected able to use his character to carry out the tax avoidance actions. The results of research that support the researcher's allegation have been proven by Maharani and Suardana (2014) and Dewi et al. (2016) who found executive character had a positive effect on tax avoidance practice. Based on the researcher's expectations and the description, the second hypothesis in this study is:

\section{$\mathrm{H}_{2}$ : There is a positive effect of executive characters on tax avoidance practice.}

\section{Effect of Audit Quality on Tax Avoidance Practice}

Y and Niandari (2018) stated in their research that the audit process really requires professionalism, accountability, and high integrity or transparency. Transparency is an important component of audit quality. To obtain high quality audited financial statements, the company tends to 
use competent auditors from trusted public accountants like KAP the big four. Annisa and Kurniasih (2012) in their research mentioned that audited annual reports by KAP the big four auditors would present higher quality results than non-big four KAP.

KAP the big four gets a good reputation from the public because audited financial reports have high credibility, so researchers suspect that companies use the service of KAP the big four when auditing financial report will reduce tax avoidance practice. The result of research supporting the researcher's allegation has been carried out by Mulyani et al. (2018) who found a negative effect on audit quality as measured by KAP the big four against tax avoidance. Based on researcher's expectations and the description, the third hypothesis in this study is:

\section{H3: There is a negative effect of audit quality on tax avoidance practice.}

Based on the theory review, literature review, and hypothesis development that have been explained, the research model can be seen in the following Figure 1:

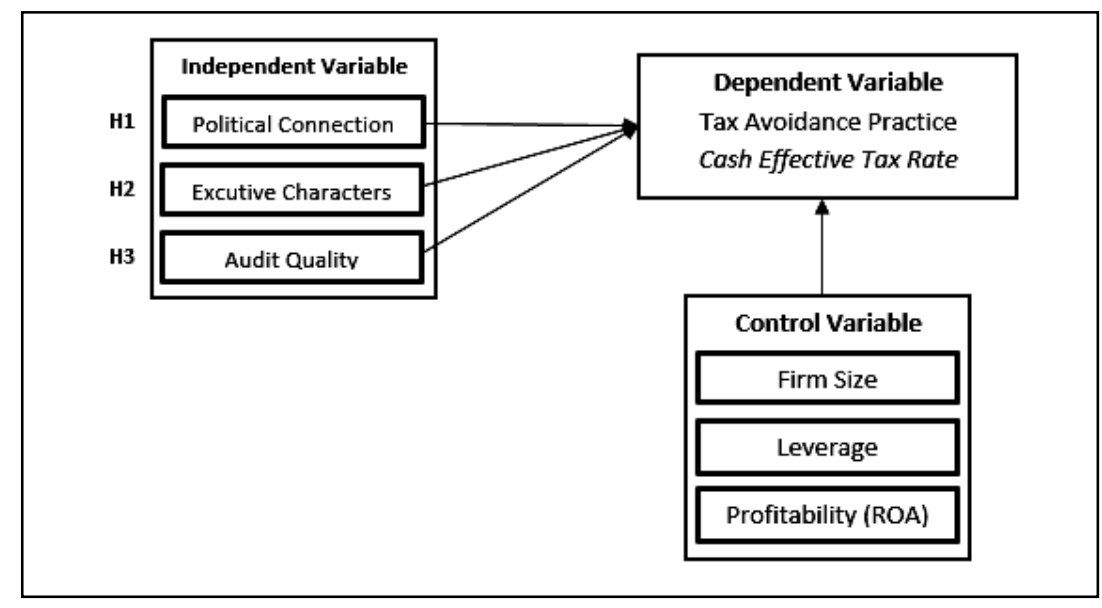

Figure 1. Research Model

\section{Research Method \\ Population and Sample}

This study uses secondary data by collecting and analyzing audited annual report data of companies listed on the IDX in 2013 - 2017 from idx.co.id. The population of this research is manufacturing companies listed on the IDX such as basic chemical industries, various industries, and consumer goods industries. The sampling technique is used probability sampling with the purposive sampling method.

\section{Operational Variables and Measurement}

Tax Avoidance Practice

Cash ETR is the value of tax payments made by the company in cash for the earnings before the company's tax (Eksandy, 2017). Cash ETR formula refers to Dyreng et al. (2008) as follows: Cash ETR $=$ Cash Tax Paid / Pre-Tax Income .

\section{Political Connection}

The independent variable of political connection can be explained using dummy variables. If the company is indicated to have a political connection, then get a score of 1 and the company that isn't indicated have a political connection, the get a score of 0. Fan et al. (2007) provide provisions that companies will be indicated having political connection if board commissioners and directors: (1) double position as a politician affiliated with political party; (2) double position as a government officials; (3) double position as military officials; (4) former government officials or former military officials. 


\section{Executive Character}

The determination independent variable of executive character can be seen from the corporate risk of a company (Paligorova, 2010). Corporate risk can be measured by the standard deviation of EBITDA (earnings before interest, taxes, depreciation, and amortization) divided by the total asset of the company. The standard deviation of corporate risk formula refers to Paligorova (2010) as follows: Risk $=$ Standard Deviation EBITDA / Total Asset.

\section{Audit Quality}

The measurement of audit quality can use a dummy variable by looking at the KAP the big four services used by the company. If the company uses the services of KAP the big four in auditing their financial reports, will give a score as 1, while companies that use services other than KAP the big four are given a score as 0 .

\section{Firm Size}

The size of the company also affects the productivity of the company seen by the profits generated, so that indirectly can influence the level of company tax payments Dharma and Ardiana (2016). Firm size formula refers to Dyreng et al. (2008) as follows: Firm Size $=$ Ln. Total Asset.

\section{Leverage}

Dharma and Ardiana (2016) and Mayangsari et al. (2015) adding leverage policy related to the amount of debt that will cause interest expense, this expense is used as a component to reduce the company's net profit so that tax payments will also decrease. The existence of leverage can encourage companies to intentionally in debt to reduce the tax expense (Suyanto and Supramono, 2012). Leverage formula refers to Kieso et al. (2010) as follows: Leverage= Total Liability / Total Asset.

\section{Profitability}

According to Utari and Supadmi (2017), when a company able to manage income and payment of its tax expense, that company is considered to earn a profit so the company doesn't practice tax avoidance. Return on Asset (ROA) formula refers to Kieso et al. (2010) as follows: ROA = Earning After Tax / Total Asset.

\section{Data Processing and Analysis Techniques}

This study uses the Eviews 9 statistical application to do data processing. The panel data regression equation model formed in this study as follows:

$$
\text { CETRit }=\alpha+\beta_{1} \text { POLCON }_{i t}+\beta_{2} \text { RISK }_{i t}+\beta_{3} Q U A L I T Y_{i t}+\beta_{4} \text { SIZEE }_{i t}+\beta_{5} L_{E V} V_{i t}+\beta_{6} \text { PROFIT }_{i t}+\varepsilon
$$

\section{Result and Discussion \\ The Results of Determining Estimation Model}

According to Basuki and Prawoto (2016), there are 3 estimation models of panel data, such as common effects, fixed effects, and random effects. Based on that test, the best estimation model in this research is the common effect model.

\section{The Results of Classic Assumption Test}

Based on a multicollinearity test which refers to Gujarati (2004) and heteroscedasticity test which refers to Ghozali (2005), it can be concluded that the data used in this study didn't experience the classic assumptions test problems.

\section{The Results of Hypothesis Test}

The Result of Data Panel Regression

The result of data panel regression using common effect as the best model can be seen in Table 1 as follows: 
Table 1. The Result of Data Panel Regression

\begin{tabular}{lrrr}
\hline \multicolumn{1}{c}{ Variable } & Coefficient & t-Test & Prob. \\
\hline C & 0.476558 & 0.597542 & 0.5507 \\
POLCON (H1) & 0.305472 & 2.811663 & 0.0053 \\
RISK (H2) & 2.272350 & 1.390853 & 0.1655 \\
QUALITY (H3) & -0.138246 & -0.986299 & 0.3249 \\
SIZE & -0.011712 & -0.303138 & 0.7620 \\
LEV & 0.599287 & 1.898389 & 0.0588 \\
PROFIT & -1.681819 & -2.536569 & 0.0118 \\
R-squared & & & 0.086447 \\
Adj R-squared & & & 0.064345 \\
N & & & 255 \\
\hline Alpha significance level of 5\% & & \\
\hline
\end{tabular}

In accordance with the regression results in table 1, the equation model of data panel regression is:

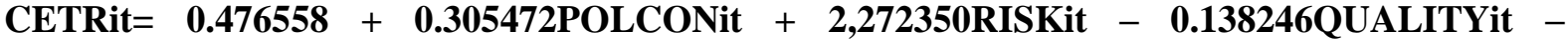 0.011712SIZEit+ 0.599287LEVit - 0.681819PROFITit (1) \\ The Result of Coefficient Determination}

The adjusted R-squared value in table I shows that political connection, executive character, audit quality, company size, leverage, and profitability are only able to explain the tax avoidance practice (CETR) of $6,4 \%$ while $93,6 \%$ is explained by other variables.

\section{The Result of Partial Hypothesis Test}

Effect of Political Connection on Tax Avoidance Practice

Based on table I with the common effect data panel regression model, the probability value of political connection (POLCON) is 0.0053 which smaller than the significance level of $0.05(0.0053<$ 0.05 ) and the coefficient is 0.305472 with positive direction. The result of this test concludes that the political connection variable has a positive and significant effect on tax avoidance practice, so $\mathrm{H}_{1}$ is supported.

Effect of Executive Character on Tax Avoidance Practice

Based on table I with the common effect data panel regression model, the probability value of an executive character (RISK) is 0.1655 which higher than the significance level of $0.050 .1655>0.05$ ) and the coefficient is 2,272350 with positive direction. The result of this test concluded that the executive character variable has a positive and no significant effect on tax avoidance practice, so $\mathrm{H}_{2}$ is not supported.

Effect of Audit Quality on Tax Avoidance Practice

Based on table I with the common effect data panel regression model, the probability value of audit quality (QUALITY) is 0.3249 which higher than the significance level of $0.05(0.3249<0.05)$ and the coefficient is -0.138246 with negative direction. The result of this test concluded that audit quality variable has a negative and no significant effect on tax avoidance practice, so $\mathrm{H}_{3}$ is not supported

\section{Conclusion Conclusions}

Based on the results of the test, some conclusions can be drawn, such as (1) Political connections have a positive and significant effect on tax avoidance practice, so that indicating there is the relationship between politically connected companies with the tax avoidance actions taken by them. These results prove that politically connected companies have the opportunity to carry out tax avoidance through their special relationships with the government. One of the opportunities that can be utilized by companies indicated by political connection is to make lobbying efforts. This effort aims to launch a tax avoidance method that is used or minimizes punishment when the method is against the rules of the government; (2) Executive character doesn't affect the tax avoidance practice which indicates that the character of a leader who is brave enough to take risks can't be used a benchmark in making decisions related to government. This result is reinforced by the theory of stewardship, which considers the executive as a person who can be trusted in carrying out the duties and responsibilities in accordance with the rules set by the government as well as in paying taxes. One 
form of trust given by the government to steward (company) is by calculating the tax expense in a self-assessment. Remember there is sense of trust, the steward must make every effort to avoid opportunistic behavior such as reducing his tax expense; (3) Audit quality as measured by KAP the big four has no effect on tax avoidance practice. This result indicates KAP the big four which generally good quality, have not been able to minimize and detect tax avoidance actions. The company's decision to conduct tax avoidance is only influenced by the company's internal management decisions so that the auditor as an external party can't influence that decision. When a company carrying out tax avoidance, an auditor who conducts an auditing process can't directly decide that the company is cheated. This becomes more complicated considering that the practice of tax avoidance is still legal in the eyes of the law, so the auditors of the KAP the big four can't influence the internal decisions in using the tax avoidance method while not violating the rules.

\section{Suggestions}

Based on limitations, there are suggestions that can be considered for further research, such as: (1) Increase the number of observation samples, not only using the manufacturing company sector but using all sectors of the company on the IDX; (2) Increase the number of periods, so that can produce more sample quantities and can represent previous years; (3) Can use another proxies besides Cash ETR which represent tax avoidance variable such as Current ETR, GAAP ETR, and Book Tax Difference; (4) Indicates that the company has political connections not only from the board of commissioners and directors but also from the company audit committee; (5) Add proxies that represent audit quality variable such as audit tenure and audit fees; (6) Adding other research variables that are through to influence the tax avoidance practice such as good corporate governance, corporate social responsibility, transfer pricing transactions, and executive-related variables such as executive incentives and executive share ownership.

\section{References}

Annisa, N.A. and Kurniasih, L. (2012), "Pengaruh Corporate Governance Terhadap Tax Avoidance”, Jurnal Akuntansi $\mathcal{E}$ Auditing, Vol. 8, pp. 126-136.

Astuti, T.P. and Aryani, Y.A. (2016), "Tren Penghindaran Pajak Perusahaan Manufaktur di Indonesia yang Terdaftar di BEI Tahun 2001-2014", Jurnal Akuntansi, Vol. 20, pp. 375-388.

Basuki, A.T. and Prawoto, N. (2016), Analisis Regresi Dalam Penelitian Ekonomi E Bisnis: Dilengkapi Aplikasi SPSS E EVIEWS, PT Rajagrafindo Persada, Depok.

Butje, S. and Tjondro, E. (2014), "Pengaruh Karakter Eksekutif dan Koneksi Politik Terhadap Tax Avoidance”, Tax E Accounting Review, Vol. 4, pp. 1-9.

Carolina, V., Natalia, M. and Debbianita. (2014), "Eksekutif Terhadap Tax Avoidance dengan Leverage Sebagai Variabel Intervening”, Jurnal Keuangan Dan Perbankan, Vol. 18, pp. 409-419.

Davis, J.H., Schoorman, F.D. and Donaldson, L. (1997), “Toward a Stewardship Theory of Management”, Journal Academy of Management Review, Vol. 22, pp. 183-199.

DeAngelo, L.E. (1981), “Auditor Size and Audit Quality”, Journal of Accounting and Economics, pp. 183-199.

Dewi, G.A. and Sari, M.M. (2015), "Pengaruh Insentif Eksekutif, Corporate Risk dan Corporate Governance pada Tax Avoidance”, E-Jurnal Akuntansi Universitas Udayana, Vol. 13, pp. 50-67.

Dewi, N., Nasir, A. and Hariadi. (2016), "Pengaruh Karakter Eksekutif, Karakteristik Perusahaan, dan Pengungkapan Tanggung Jawab Sosial Perusahaan Terhadap Penghindaran Pajak”, JOM Fekon, Vol. 3, pp. 1006-1021.

Dharma, I.M. and Ardiana, P.A. (2016), "Pengaruh Leverage, Intensitas Aset Tetap, Ukuran Perusahaan, dan Koneksi Politik Terhadap Tax Avoidance”, E-Jurnal Akuntansi Universitas Udayana, Vol. 15, pp. 584-613.

Donaldson, L. and Davis, J.H. (1991), "Stewardship Theory or Agency Theory: CEO Governance and Shareholder Returns”, Australian Journal of Management, Vol. 16, pp. 49-65.

Dyreng, S.D., Hanlon, M. and Maydew, E.L. (2008), “Long-Run Corporate Tax Avoidance”, The Accounting Review, Vol. 83, pp. 61-82.

Eksandy, A. (2017), "Pengaruh Komisaris Independen, Komite Audit, dan Kualitas Audit Terhadap Penghindaran Pajak (Tax Avoidance)", Competitive, Vol. 1, pp. 1-55.

Faccio, M. (2006), “Politically-Connected Firms: Can They Squeeze the State?”, American Economic Review, pp. 155.

Fan, J.P., Wong, T. and Zhang, T. (2007), "Politically Connected CEOs, Corporate Governance, and Post-IPO Performance of China's Newly Partially Privatized Firms”, Journal of Financial Economics, Vol. 84, pp. 330357.

Ferdiawan, Y. and Firmansyah, A. (2017), "Pengaruh Political Connection, Foreign Activity, dan Real Earnings Management Terhadap Tax Avoidance”, Jurnal Riset Akuntansi Dan Keuangan, Vol. 5, pp. 1601-1624.

Freeman, R.E. (1984), Strategic Management: A Stakeholder Approach, Pitman, Boston. 
Ghozali, I. (2005), Aplikasi Analisis Multivariate Dengan Program SPSS, Ketiga., Badan Penerbit Universitas Diponegoro, Semarang.

Ghozali, I. and Chariri, A. (2007), Teori Akuntansi, Badan Penerbit Universitas Diponegoro, Semarang.

Gujarati, D.N. (2004), Basic Econometrics, Four Editi., McGraw-Hill International Edition, Singapore.

Hanlon, M., and Heitzman, S. (2010), “A Review of Tax Research”, Journal of Accounting and Economics, Vol. 50, pp. 127-178.

Jensen, M.C. and Meckling, W.H. (1976), “Theory of the Firm: Managerial Behavior, Agency Costs, and Ownership Structure”, Journal of Financial Economics, pp. 1-77.

Kartana, I.W. and Wulandari, N.G. (2018), "Pengaruh Karakter Eksekutif, Karakteristik Perusahaan dan Corporate Governance Terhadap Tax Avoidance", Jurnal KRISNA: Kumpulan Riset Akuntansi, Vol. 10, pp. 1-13.

Kementerian Keuangan. (2019a), "Laporan Belanja Perpajakan 2016-2017", available at: http://www.fiskal.kemenkeu.go.id/dw-taxexpenditure.asp (accessed 10 May $1 \mathrm{BC}$ ).

Kementerian Keuangan. (2019b), “Informasi APBN Kita 2019”, available at: https://www.kemenkeu.go.id/publikasi/apbn-kita/ (accessed o May 1BC).

Kieso, D.E., Weygandt, J.J. and Warfield, T.D. (2010), Intermediate Accounting: IFRS Edition, Volume 1, John Wiley \& Sons.

Kim, C. and Zhang, L. (2016), “Corporate Political Connections and Tax Aggressiveness”, Contemporary Accounting Research, Vol. 33, pp. 78-144.

Lestari, G.A. and Putri, I.A. (2017), "Pengaruh Corporate Governance, Koneksi Politik, dan Leverage Terhadap Penghindaran Pajak”, E-Jurnal Akuntansi Universitas Udayana, Vol. 18, pp. 2028-2054.

Li, C., Wang, Y., Wu, L. and Xiao, J.Z. (2016), "Political Connections and Tax-induced Earnings Management: Evidence from China", The European Journal of Finance, pp. 1-38.

Low, A. (2009), "Managerial Risk-Taking Behavior and Equity-Based Compensation", Journal of Financial Economics, pp. 1-42.

Maharani, I.G. and Suardana, K.A. (2014), "Pengaruh Corporate Governance, Profitabilitas dan Karakteristik Eksekutif Pada Tax Avoidance Perusahaan Manufaktur”, E-Jurnal Akuntansi Universitas Udayana, Vol. 9, pp. 525-539.

Mayangsari, C., Zirman and Haryani, E. (2015), "Pengaruh Kompensasi Eksekutif, Kepemilikan Saham Eksekutif, Preferensi Risiko Eksekutif dan Leverage Terhadap Penghindaran Pajak (Tax Avoidance)”, JOM Fekon, Vol. 2, pp. 1-15.

Mulyani, S., Wijayanti, A. and Masitoh, E. (2018), "Pengaruh Corporate Governance Terhadap Tax Avoidance", Jurnal Riset Akuntansi Dan Bisnis Airlangga, Vol. 3, pp. 322-340.

Nengsih, H., Suryani, E. and Kurnia. (2018), "Pengaruh Karakter Eksekutif, Profitabilitas dan Ukuran Perusahaan Terhadap Tax Avoidance (Studi Pada Perusahaan Manufaktur Subsektor Consumer Goods yang Terdaftar di Bursa Efek Indonesia Tahun 2012-2016", E-Proceeding of Management, Vol. 5, pp. 3421-3428.

Novita, N. (2016), "Executive Characters, Gender, and Tax Avoidance: A Study on Manufacturing Companies in Indonesia”, Advances in Economics, Business and Management Research, Vol. 15, pp. 92-95.

Paligorova, T. (2010), "Corporate Risk-Taking and Ownership Structure”, Bank of Canada Working Paper, pp. 1-41.

Pranoto, B.A. and Widagdo, A.K. (2016), "Pengaruh Koneksi Politik dan Corporate Governance Terhadap Tax Aggressiveness", Seminar Nasional Dan The zrd Call for Syariah Paper, pp. 472-486.

Purwanti, S.M. and Sugiyarti, L. (2018), "Pengaruh Intensitas Aset Tetap, Pertumbuhan Penjualan dan Koneksi Politik Terhadap Tax Avoidance”, Jurnal Riset Akuntansi Dan Keuangan, Vol. 5, pp. 1625-1642.

Suyanto, K.D. and Supramono. (2012), "Likuiditas, Leverage, Komisaris Independen, dan Manajemen Laba Terhadap Agresivitas Pajak Perusahaan”, Jurnal Keuangan Dan Perbankan, Vol. 16, pp. 167-177.

Tehupuring, R. and Rossa, E. (2016), "Pengaruh Koneksi Politik dan Kualitas Audit Terhadap Praktik Penghindaran Pajak di Lembaga Perbankan yang Terdaftar di Pasar Modal Indonesia Periode 2012-2014”, Prosiding Seminar Nasional INDOCOMPAC, pp. 366-376.

Utari, N.K. and Supadmi, N.L. (2017), "Pengaruh Corporate Governance, Profitabilitas dan Koneksi Politik pada Tax Avoidance”, E-Jurnal Akuntansi Universitas Udayana, Vol. 18, pp. 2202-2230.

Watts, R.L. and Zimmerman, J.L. (1990), "Positive Accounting Theory: A Ten Year Perspective", The Accounting Review, Vol. 65, pp. 131-156.

Y, R.H., and Niandari, N. (2018), "Tax Avoidance Practice: Political Connection, Firm Characteristics, and Audit Quality Test at Banking Industrial in Indonesia”, International Journal of Business Management and Economic Research (IJBMER), Vol. 9, pp. 1296-1303. 